\title{
Mineral profile and proximate analysis of fresh and waste water irrigated cabbage from Quetta Balochistan
}

\author{
Muhammad Tayyeb ${ }^{1 *}$, Nadeem Rashid ${ }^{1}$, Safi Ullah Khan Achakzai ${ }^{1}$, \\ Saif Ur Rehman ${ }^{1}$, Waseem Akhtar ${ }^{1}$, Kamran Baseer ${ }^{2}$ and Muhammad \\ Sabir $^{3}$ \\ 1. CASVAB, University of Balochistan Quetta-Pakistan \\ 2. Livestock and dairy development department Quetta, Balochistan-Pakistan \\ 3. Botany Department, University of Balochistan Quetta-Pakistan \\ *Corresponding author's email: mtayyeb2017@gmail.com
}

Citation

Muhammad Tayyeb, Nadeem Rashid, Safi Ullah Khan Achakzai, Saif Ur Rehman, Waseem Akhtar, Kamran Baseer and Muhammad Sabir. Mineral profile and proximate analysis of fresh and waste water irrigated cabbage from Quetta Balochistan. Pure and Applied Biology. Vol. 6, Issue 3, pp882-888.

http://dx.doi.org/10.19045/bspab.2017.60093

Received: $28 / 03 / 2017$

Revised: 05/07/2017

Accepted: 09/07/2017

Online First: 21/07/2017

\section{Abstract}

In developing countries especially in Pakistan due to insufficient fresh water resources, wastewater is largely used for irrigation purposes. The wastewater cultivated vegetables due to presence of toxic material might be injurious to human health. The present study was designed to interpret the effect of waste and fresh water on the nutritional value of Cabbage (Brassica oleracea). For the purpose of macro and micro nutrients along with proximate contents of the randomly selected cabbage samples from both irrigation types were analysed. The cabbage harvested from wastewater plots showed more accumulation of heavy metals than that of fresh water. The macro and micro nutrients $(\mathrm{mg} / \mathrm{g})$ in waste and fresh water cabbage were Calcium (Ca) (395.00, 399.60), Magnesium (Mg) (226.82, 234.00), Iron (Fe) (1.01, 1.06), Chromium (Cr) (0.74, 0.83), Nickle (Ni) (0.86, 0.91), Cadmium (Cd) $(0.15,0.14)$, Lead $(\mathrm{Pb})(0.72,0.07)$, Copper $(\mathrm{Cu})(1.32,1.85)$ and Zinc (Zn) (0.24, 0.38), respectively. Whereas, the macro and micro minerals contents of the fresh and wastewater $\mathrm{mg} / \mathrm{l}$ were $\mathrm{Ca}$ (35.61, 37.39), $\mathrm{Mg}(23.62,24.97), \mathrm{Fe}(0.16,0.18), \mathrm{Cr}(0.05,0.06), \mathrm{Ni}(0.006,0.007), \mathrm{Cd}(0.16$, $0.18), \mathrm{Pb}(0.019,0.07), \mathrm{Cu}(0.007,0.02)$ and $\mathrm{Zn}(0.28,0.57)$, respectively. The result for the proximate composition of freshly harvested $(\mathrm{g} / 100 \mathrm{~g})$ revealed Crude fibre $(3.24$ and $3.24 \%)$, Crude protein (1.80 and 1.58 \%), Ether extract (6.42 and 6.22 \%), Dry matter (6.94 and $7.18 \%$ ), Moisture contents (93.02 and $92.8 \%$ ) and Ash (0.67 and $0.61 \%)$. The study showed that cabbage is rich in appreciable amount of macro and micro nutrients, therefore possess high nutritional values in human consumption but continuous accumulation of these metals can pose severe threats to health of people. Keywords: Brassica Oleracea; Heavy metals; Proximate analysis; Wastewater; Vegetables; Atomic absorption spectroscopy

\section{Introduction}

Vegetables; the herbaceous fresh portions of plants contain certain ingredients which play vital role in different metabolic pathways and physiological functions [1, 2]. They offer the prompt and least expensive source 
of fibres, minerals and vitamins to the majority of population of developing countries [3]. These are helpful for the maintenance of health, repair and build-up of the body and prevention of various diseases [4]. Vegetables contain minerals, which take part to maintain body $\mathrm{pH}$, regulate osmotic pressure and act as coenzymes. These minerals neutralize the acidity formed by other foods, particularly those of animal sources and helpful in providing alkaline effects [2]. The well represented composition of minerals include $\mathrm{Ca}, \mathrm{Fe}, \mathrm{Cu}, \mathrm{P}, \mathrm{Zn}, \mathrm{Cl}$, and $\mathrm{Na}$. It is recommended that adults should consume at least $400 \mathrm{~g}$ (or five servings a day) of fruits and vegetables [5].

Cabbage (Brassica oleracae var. capitata L) is a green leafy vegetable belongs to the genus Brassica, of family Brassicaceae [6]. It is an excellent source of vitamins, minerals and dietary fibre [7]. Cabbage has been used in ancient times both as food and medicine. It is helpful in the management and/or treatment of several ailments and disease conditions including yeast infections, gout and rheumatism, relieving of gastric pain and hyperacidity, short-term rapid weight loss, reduction of painful breast engorgement in breast feeding women, hangover remedy, urine retention, menstrual pain or irregularities, scurvy, immune stimulant, constipation and as a poultice to clean infected wounds [8].

Good quality water is scarce in developing countries because of overwhelmed population. Use of sewage water (wastewater) in agriculture is centuries old practice and now a days got more attention in many parts of the world due to increasing water demand [9]. In Pakistan, about $25 \%$ of the total vegetables are irrigated with wastewater that increases the risk of heavy metal toxicity [10]. Leafy vegetables including cabbage grow quite well with sewage water irrigation. However, vegetables grown in the presence of sewage water may accumulate heavy metals that could be transferred through food chain to human and animals and may cause serious health hazards [11].

The evaluation of nutrients of vegetables is of great nutritional importance [12] and is the trend of the day throughout the world. Presently there is very little or no data is available about Quetta, regarding the use of waste and fresh water. Pakistan pertaining to the concentration of sewage water contents and their accumulation in vegetable receiving irrigation using municipal sewage water. Therefore the current study was designed to examine the effect of irrigation of fresh water (tube well) and municipal wastewater on the nutritional quality of cabbage regarding mineral profile and proximate analysis components.

\section{Materials and methods}

Cabbage samples $(n=10$, each $1 \mathrm{~kg})$ were randomly collected from the fields irrigated with fresh (tube-well) and wastewater sources, located near Samungli, Spini and Sabzal roads, Quetta where both (sources and their cultivated cabbage plants) were available. The collected samples were transferred to Toxicology laboratory of Centre for Advanced Studies in Vaccinology and Biotechnology (CASVAB), university of Balochistan for further processing and analysis to determine mineral (macro and micro) profile and proximate contents.

\section{Sample processing}

The samples were washed with distilled water, dried in hot air oven at $35^{\circ} \mathrm{C}$, grinded (40 mesh) and stored in the polyethylene bags at $4^{\circ} \mathrm{C}$ until used for further analysis.

\section{Mineral profile}

Mineral contents were determined following the method previously adopted [13]. Briefly; 0.5 gram powdered sample (in duplicate) was placed in a crucible and added a few drops of concentrated nitric acid. Dry ashing was supported with a muffle furnace by 
stepwise rise of temperature up to $550^{\circ} \mathrm{C}$ and then left to ash at this temperature for 6 hours. Then kept in a desiccator, rinsed with 3 Molar hydrochloric acid (3N HCL), filtered with Whatman No. 1 filter paper, poured into a $50 \mathrm{ml}$ volumetric flask and made the final volume $50 \mathrm{ml}$ by adding $3 \mathrm{~N}$ hydrochloric acid. The minerals including $\mathrm{Ca}, \mathrm{Mg}, \mathrm{Fe}, \mathrm{Cr}, \mathrm{Ni}, \mathrm{Cd}, \mathrm{Pb}, \mathrm{Cu}$ and $\mathrm{Zn}$ were determined by atomic absorption spectrophotometer (M series AA Spectrometer, Thermo Electron Corporation) results were expressed in $\mathrm{mg} / 100 \mathrm{~g}$.

The Proximate composition including crude protein, dry matter, moisture, ash, crude fibre and ether extract contents were analysed adopting the methodology of [14] briefly

\section{Crude fibre}

Two grams of moisture and fat free sample was subjected to acid $\left(1.25 \% \mathrm{H}_{2} \mathrm{SO}_{4}\right)$ and alkali $(\mathrm{NaOH})$ digestion for 30 minutes. The contents were dried at a $100{ }^{\circ} \mathrm{C}$ using hot air oven till constant weight. The dried residue was ignited in muffle furnace at $550^{\circ} \mathrm{C}$ for 20 minutes. Loss in weight was reported as crude fibre.

Crude fibre $=\underline{\text { Loss in weight on ignition }} \times 100$

\section{Crude protein}

$$
\text { Weight of sample }
$$

Cabbage samples were digested in presence of catalyst i.e. Mercuric sulfate $\left(\mathrm{HgSO}_{4}\right)$ and Potassium sulfate $\left(\mathrm{K}_{2} \mathrm{SO}_{4}\right)$ with concentrated sulfuric acid till it become clear. The digested material was cooled and diluted with distilled water. An aliquot was transferred to Kjeldhal distillation apparatus for distillation in the presence of $40 \% \mathrm{NaOH}$ solution and Zinc dust. The ammonia formed was trapped with $2 \%$ boric acid solution added with indicator. The distillate was titrated to light pink against $0.1 \mathrm{~N}$ sulfuric acid. The nitrogen percentage was calculated by using the following formula. Nitrogen $\%=\mathrm{ml} 0.1 \mathrm{~N} \mathrm{H}_{2} \mathrm{SO}_{4} \times 0.0014 \times 250 \times 100$ $\mathrm{W} 1 \times 10$
Where Conversion factor $=100 / \mathrm{N}(\mathrm{N} \%$ in fruit products).

\section{Ether extract}

The ether extract was determined by extraction with petroleum ether (PE) using a Soxhlet system (boiling point range of 40$60^{\circ} \mathrm{C}$ ). Extraction was carried out with 25 $\mathrm{ml} \mathrm{PE}$ and $1 \mathrm{~g}$ of dried sample with for 3-4 hours. At $105{ }^{\circ} \mathrm{C}$ PE extract was evaporated to dryness. Percentage of crude fat was known by calculating and weighing residue on dry weight basis.

Ether extract $=\underline{\mathrm{W}_{2}}-\underline{\mathrm{W}_{1}} \times 100$

$$
\mathrm{W}_{3}
$$

Where $\mathrm{W} 1$ = Weight of empty flask, W2 = Weight of flask + fat and W3 = Weight of sample taken.

\section{Moisture}

$5 \mathrm{gm}$ sample was placed in hot air oven at $80^{\circ} \mathrm{C}$ up to constant weight and recorded the moisture \%age

Moisture $\%=\underline{\text { Weight of fresh sample }- \text { weight of dried sample }} \times 100$

Ash Weight of fresh sample

The 10 gram sample was placed in crucible and kept in Muffle furnace at $550^{\circ} \mathrm{C}$ for 6 hours, desiccated and recorded the weight.

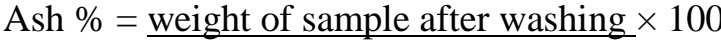

\section{Data analysis}

Total weight of sample

The data was statistically analysed with the help of computer software SPSS 16 for windows using independent sample student's t-test. Excel 2010 was used where needed.

\section{Result}

The mineral profile $(\mathrm{mg} / 100 \mathrm{~g})$ of cabbage irrigated with fresh and wastewater sources (Table 1) were $\mathrm{Ca}$ (395.00, 399.60), $\mathrm{Mg}$ (226.82, 234.00), Fe (1.01, 1.06), Cr (0.74, 0.83), Ni (0.86, 0.91), Cd (0.15, 0.14), Pb (0.72, 0.07), $\mathrm{Cu}(1.32,1.85)$ and $\mathrm{Zn}(0.24$, 0.38). Whereas the mineral contents $(\mathrm{mg} / 1001)$ of the water types (fresh and waste) presented in Table 2 were Ca (35.61, 37.39), $\mathrm{Mg}$ (23.62, 24.97), Fe (0.16, 0.18), Cr (0.05, 0.06), Ni (0.006, 0.007), Cd (0.16, 
$0.18), \mathrm{Pb}(0.019,0.07), \mathrm{Cu}(0.007,0.02)$ and $\mathrm{Zn}(0.28,0.57)$. Comparison and analyses of results showed non-significant $(\mathrm{P}>0.05)$ difference in minerals viz. $\mathrm{Ca}, \mathrm{Mg}, \mathrm{Fe}, \mathrm{Cr}$, $\mathrm{Ni}$ and $\mathrm{Cd}$ and significant difference between $\mathrm{Pb}, \mathrm{Cu}$ and $\mathrm{Zn}$ in both the wastewater and fresh water cabbage with their respective water cultivated.
The proximate analysis of cabbage samples (Table 3) Crude fibre contents (3.24 and $3.24 \%)$, Crude protein (1.80 and $1.58 \%$ ), Ether extract (6.42 and 6.22\%), Dry matter (6.94 and $7.18 \%)$, Moisture contents (93.02 and $92.8 \%$ ) and Ash (0.67 and $0.61 \%)$. Result shows there is non-significant $(\mathrm{P}>0.05)$ difference between fresh and wastewater grown cabbage.

Table 1. Minerals in fresh and wastewater irrigated cabbage (mg/g)

\begin{tabular}{|l|l|c|c|}
\hline S.No & Menials & $\begin{array}{l}\text { Fresh water irrigated cabbage } \\
\text { (Mean } \pm \text { SD) }\end{array}$ & $\begin{array}{l}\text { Waste water irrigated cabbage } \\
\text { (Mean } \pm \text { SD) }\end{array}$ \\
\hline 1 & $\mathrm{Ca}$ & $395.00^{\mathrm{a}} \pm 4.00$ & $399.60^{\mathrm{a}} \pm 5.02$ \\
\hline 2 & $\mathrm{Mg}$ & $226.82^{\mathrm{a}} \pm 5.46$ & $234.00^{\mathrm{a}} \pm 5.47$ \\
\hline 3 & $\mathrm{Fe}$ & $1.01^{\mathrm{a}} \pm 0.03$ & $1.06^{\mathrm{a}} \pm 0.05$ \\
\hline 4 & $\mathrm{Cr}$ & $0.74^{\mathrm{a}} \pm 0.093$ & $0.83^{\mathrm{a}} \pm 0.091$ \\
\hline 5 & $\mathrm{Ni}$ & $0.86^{\mathrm{a}} \pm 0.037$ & $0.91^{\mathrm{a}} \pm 0.051$ \\
\hline 6 & $\mathrm{Cd}$ & $0.15^{\mathrm{a}} \pm 0.037$ & $0.14 \pm 0.039$ \\
\hline 7 & $\mathrm{~Pb}$ & $0.72^{\mathrm{a}} \pm 0.071$ & $0.07^{\mathrm{b}} \pm 0.007$ \\
\hline 8 & $\mathrm{Cu}$ & $1.32^{\mathrm{a}} \pm 0.12$ & $1.85^{\mathrm{b}} \pm 0.09$ \\
\hline 9 & $\mathrm{Zn}$ & $0.24^{\mathrm{a}} \pm 0.08$ & $0.38^{\mathrm{b}} \pm 0.07$ \\
\hline
\end{tabular}

Means followed by different letters in the same row are significantly different at $(\mathrm{P}<0.05)$

Table 2. Fresh and wastewater minerals composition (mg/l)

\begin{tabular}{|l|l|c|c|}
\hline S. No & Minerals & Fresh water $($ Mean \pm SD) & Waste water $($ Mean \pm SD) \\
\hline 1 & $\mathrm{Ca}$ & $35.61^{\mathrm{a}} \pm 2.16$ & $37.39^{\mathrm{a}} \pm 1.68$ \\
\hline 2 & $\mathrm{Mg}$ & $23.62^{\mathrm{a}} \pm 0.7$ & $24.97^{\mathrm{a}} \pm 2.09$ \\
\hline 3 & $\mathrm{Fe}$ & $0.16^{\mathrm{a}} \pm 0.03$ & $0.18^{\mathrm{a}} \pm 0.04$ \\
\hline 4 & $\mathrm{Cr}$ & $0.05^{\mathrm{a}} \pm 0.01$ & $0.06^{\mathrm{a}} \pm 0.01$ \\
\hline 5 & $\mathrm{Ni}$ & $0.006^{\mathrm{a}} \pm 0.002$ & $0.007^{\mathrm{a}} \pm 0.002$ \\
\hline 6 & $\mathrm{Cd}$ & $0.16^{\mathrm{a}} \pm 0.029$ & $0.18^{\mathrm{a}} \pm 0.021$ \\
\hline 7 & $\mathrm{~Pb}$ & $0.019^{\mathrm{a}} \pm 0.003$ & $0.07^{\mathrm{b}} \pm 0.007$ \\
\hline 8 & $\mathrm{Cu}$ & $0.007^{\mathrm{a}} \pm 0.001$ & $0.02^{\mathrm{b}} \pm 0.008$ \\
\hline 9 & $\mathrm{Zn}$ & $0.28^{\mathrm{a}} \pm 0.04$ & $0.57^{\mathrm{b}} \pm 0.08$ \\
\hline
\end{tabular}

Means followed by different letters in the same row are significantly different at $(\mathrm{P}<0.05)$

Table 3. Proximate composition on dry matter basis (gm/100gm)

\begin{tabular}{|l|l|c|c|}
\hline S. No & $\begin{array}{l}\text { Proximate } \\
\text { contents }(\%)\end{array}$ & $\begin{array}{l}\text { Fresh water irrigated cabbage } \\
(\text { Mean } \pm \text { SD) }\end{array}$ & $\begin{array}{l}\text { Waste water irrigated cabbage } \\
(\text { Mean } \pm \text { SD) }\end{array}$ \\
\hline 1 & Fibre & $3.42 \pm 1.12^{\mathrm{a}}$ & $3.42 \pm 0.67^{\mathrm{a}}$ \\
\hline 2 & Protein & $1.80 \pm 0.51^{\mathrm{a}}$ & $1.58 \pm 0.54^{\mathrm{a}}$ \\
\hline 3 & Ether Extract & $6.42 \pm 1.35^{\mathrm{a}}$ & $6.22 \pm 1.00^{\mathrm{a}}$ \\
\hline 4 & Dry Matter & $6.94 \pm 0.67^{\mathrm{a}}$ & $92.18 \pm 0.53^{\mathrm{a}}$ \\
\hline 5 & Moisture & $93.02 \pm 0.63^{\mathrm{a}}$ & $0.64^{\mathrm{a}}$ \\
\hline 6 & Ash & $0.67 \pm 0.19^{\mathrm{a}}$ & $08^{\mathrm{a}}$ \\
\hline
\end{tabular}

Means followed by different letters in the same row are significantly different at $(\mathrm{P}<0.05)$ 


\section{Discussion}

Vegetables are integral part of balanced diet and play a vital role in the maintenance of good health [2]. Cabbage is a good source of minerals like $\mathrm{Ca}, \mathrm{Fe}, \mathrm{P}, \mathrm{Na}$ and $\mathrm{K}$. Nutrients are helpful in forming a strong immune system, thus assisting body to absorb, digest and utilize nutrients [2]. Minerals are needed for vital body functions i.e. acid base and water balance etc. $\mathrm{Na}$ and $\mathrm{K}$ are used as electron carrier in the body [2]. Fe being part of hemoglobin is important in the hemoglobin formation, recommended for anaemic patients [15]. Ca and $\mathrm{P}$ are found in the body especially in bones. Ca is necessary for nails, hair, teeth and bones [16]. Whereas in diseases like osteoporosis, renal damage, kidney stones, stroke, hypertension, hypercalciuria, and cardiac dysfunctions $\mathrm{P}$ have a protective role [17]. $\mathrm{Zn}$ is essential in cofactor of many enzymatic activities and in cellular growths [18]. $\mathrm{Cr}$ is involved in various metabolic reactions [4]. $\mathrm{Cu}$ is required for erythropoiesis and necessary for the survival of red blood cells. However in high concentrations causes diarrhea, vomiting and liver damage [19].

The heavy metals found in both fresh and wastewater samples and in cabbage irrigated with both the water were below the critical limits of wastewater by world and health organization (WHO) and food and agriculture organization (FAO) found in safe limits although the wastewater sample was a bit higher in both the water and cabbage. Major source of heavy metals accumulation in plants are due to humans and natural. Human sources include mining extraction, nuclear power, metal finishing and electroplating and nuclear power plants whereas natural sources are aerosol particles, soil erosion and urban run offs [20]. Extensive use of domestic and industrial effluents for irrigation purpose causes accumulation of heavy metals in soil, lead to their raised levels in plants through bioaccumulation. Ingestion of such plants pose a potential threat to human and animal health [21].

The fibre contents in cabbage were similar [22]. It helps to reduce hypertension, coronary heart disease and serum cholesterol level [22]. Moisture content was in line with [2-4]. Moisture present in food items is a good source of water and it is deliberated, $20 \%$ to $30 \%$ of total water consumption should come from food [23]. Moisture in leafy vegetables is indicative of its perishability and freshness. However, elevated levels of moisture in leafy vegetables causes spoilage hence susceptible to microbes [24]. Protein contents were in agreement with [4-25]. Protein being the structural material of the body necessary for the formation of muscles, blood and body fluids etc. One gram of protein is known to supply the body with about 4 Kcal. Fats are important in terms of their important functions like sterol hormones, nervous system activities, enzymatic reactions and cell membrane structure. Energy provided by 1 gram of fat is more than double the energy given by carbohydrate or protein per unit weight i.e. 9 kcal [25]. Ash content which is a measure of the inorganic matter [26]. Ash contents identified were in line with [4-25].

\section{Conclusion and recommendations}

Present study revealed a number of positive effects of cabbage such as presence of minerals and proximate contents, which are beneficial for the health. It is concluded that the comparative nutritional analysis of cabbage irrigated with sewage water contain higher values of some heavy metals as compared to that grown with tube well (fresh) water. Use of sewage water for irrigation purposes poses a high risk of heavy metals accumulation in vegetables that may lead to several health problems. 


\section{Authors' contributions}

Conceived and designed the experiments: $\mathrm{M}$ Tayyeb \& N Rashid, Performed the Experiments: M Tayyeb \& N Rashid, Analyzed the Data: N Rashid \& K Baseer, Contributed reagents/ materials/ analysis tools: SK Achakzai, S Rehman \& Akhtar, Wrote the paper: M Tayyeb \& M Sabir.

\section{References}

1. Schwarz K (1977). Clinical chemistry and chemical toxicology of metals (1977): SS Browred Elsevier Amsterdam 135.

2. Caunii A, Cuciureanu R, Zakar AM, Tonea E \& Giuchici C (2010). Chemical composition of common leafy vegetables. Studia UniversitatisVasile Goldiş 20: 4548.

3. Lyaka YA, Idris S, Alawode RA \& Bagudo BU (2014). Nutrient content of selected edible leafy vegetables. American J Appl Chemistry 2: 42-45.

4. Hanif $R$, Iqbal Z, Iqbal $M$, Hanif $S \&$ Rasheed M (2006). Use of vegetables as nutritional food: role in human health. Journal of Agricultural and Biological Science 1: 18-20.

5. WHO (World Health Organization) (1989). Health guidelines for the use of wastewater in agriculture and aquaculture. Technical Report Series No 776. World Health Organization. Switzerland, Geneva.

6. Katz SH \& Weaver WW (2003). Encyclopedia of food and culture. Scribner.

7. Adeniji OT, Swai I, Oluoch MO, Tanyongana R \& Aloyce A (2010). Evaluation of head yield and participatory selection of horticultural characters in cabbage (Brassica oleraceae var. capitata). Journal of Plant Breeding and Crop Science 2: 243-250.

8. Ogbede SC, Saidu AN, Kabiru AY \& Busari MB (2015). Nutrient And AntiNutrient Compositions Of Brassica
Oleracae Var. Capitata L.IOSR Journal Of Pharmacy 3: 19-25.

9. Ghafoor A, Rauf A, Arif M \& Muzaffar W (1994). Chemical composition of effluents from different industries of the Faisalabad city. Pak J Agri Sci 31: 4.

10. Ensink JH, Mahmood T, Van der Hoek W, Raschid-Sally L \& Amerasinghe FP (2004). A nationwide assessment of wastewater use in Pakistan: An obscure activity or a vitally important one? Water policy 6: 197-206.

11. Balkhair KS \& Ashraf MA (2016). Field accumulation risks of heavy metals in soil and vegetable crop irrigated with sewage water in western region of Saudi Arabia. Saudi journal of biological sciences 23: 32-44.

12. Hussain J, Khan AL, Rehman N, Hamayun M, Shah T, Nisar M \& Lee I (2009). Proximate and nutrient analysis of selected vegetable species: A case study of Karak region, Pakistan. African Journal of Biotechnology 8: 12.

13. Baloch AB, Xia X \& Sheikh SA (2015). Proximate and Mineral Compositions of Dried Cauliflower (Brassica Oleracea L.) Grown In Sindh, Pakistan. Journal of Food and Nutrition Research 3: 213219.

14. AOAC (2000). Animal Feed In: Official Methods of Analyses. Association of official analytical chemists. Arrington, Virginia. USA pp: 1-54.

15. Mariga IK, Mativha L \& Maposa D (2012). Nutritional assessment of a traditional local vegetable (Brassica oleracea var. acephala). Journal of Medicinal Plants Research 6: 784-789.

16. Kambizi L \& Lewu MN (2013). Comparative nutritional assessment of selected leafy vegetables. International Conference on Biotechnology and Food Technology. July 14-15, 2015 Harare (Zimbabwe). 
17. Demigné C, Sabboh H, Rémésy C \& Meneton P (2004). Protective effects of high dietary potassium: nutritional and metabolic aspects. The Journal of nutrition 134: 2903-2906.

18. Cámara F \& Amaro MA (2003). Nutrional aspect of zinc availability. International journal of food sciences and nutrition 54: 143-151.

19. Johnson WT (2005). Nutritional and neuroscienc. Taylor \& Francis, Boca Raton; $17 \mathrm{p}$.

20. Akpor OB, Ohiobor GO \& Olaolu TD (2014). Heavy metal pollutants in wastewater effluents: sources, effects and remediation. Advances in Bioscience and Bioengineering 2: 37-43.

21. Mushtaq N \& Khan K (2010). Heavy metals contamination of soils in response to wastewater irrigation in Rawalpindi region. Pak J Agr Sci 47: 215-224.

22. Rodriguez R, Jimenez A, FernándezBolaños J, Guillén R \& Heredia A (2006). Dietary fibre from vegetable products as source of functional ingredients. Trends in Food Science \& Technology 17: 3-15.

23. Guelinckx I, Tavoularis G, König J, Morin C, Gharbi H \& Gandy J (2016). Contribution of water from food and fluids to total water intake: Analysis of a French and UK Population Surveys. Nutrients 8: 630.

24. Fennema OR \& Tannenbaum SR (1996). Introduction to food chemistry. Food science and technology new york marcel dekker 1-16.

25. Agea JG, Kimondo JM, Woiso DA, Okia CA, Obaa BB, Isubikalu P \& Teklehaimanot Z (2014). Proximate composition, vitamin $\mathrm{C}$ and betacarotene contents of fifteen selected leafy wild and semi-wild food plants (WSWFPs) from Bunyoro-Kitara Kingdom. Uganda. Journal of Natural Product and Plant Resources 4: 1-12.

26. Mark R, Church S, Pinchen H \& Finglas $P$ (2013). Nutrient analysis of fruit and vegetables. Analytical report 24-49. 